James Cone's legacy in Africa: Confession as political praxis in the Kairos Document

\author{
O U Kalu ${ }^{1}$
}

(McCormick Theological Seminary, Chicago, U S A)

\title{
ABSTRACT \\ James Cone's legacy in Africa: Confession as political praxis in the Kairos Document
}

This reflection sets out to achieve three goals: the key is to show the legacy of James Cone from a global perspective, specifically his contributions to the development of African theology. The second is the irony that Cone was influenced by Karl Barth's Barmen declaration in his response to the outrage against blacks in the United States in the violent late 1960s. This dimension has escaped scholarly attention. Thirdly, both Cone and the Barmen declaration influenced South African theologians who scripted the Kairos Document. Each party contextualized the use of the strategy; but for all, confession served as a form of political praxis.

\section{INTRODUCTION: THE PROPHET, THE WATCHMAN AND THE MADMAN}

In the ministry of the church, it is understood that there are many ways of expressing the core of the gospel and sharing its resources with people. Simply, one may preach or proclaim it from the rooftop; teach its cardinal principles or witness to others about its salvific power. The Greek words are rich and specific about each variety of expression. Confessions resemble the witness act and challenge those who say that they belong to Christ to live like him. From this perspective, a confession is what Christians should do at all times; all life is confession and it is one of the marks of a church. There is a mandate to testify to the faith once delivered to the saints in and out of season. Yet there are moments when the people of God in a place declare about the quality and character of their lifestyle. It is said that the tiger does not sing about its tigritude but in Christian pilgrimage, the pilgrims are often forced to blow their trumpets and declare their identity rather loudly not because the trumpets may rust

1 Research Associate of Prof J W Hofmeyr, Department of Church History, University of Pretoria. 
from disuse but to avoid mistaken identity and to arouse those who are at ease in Zion. This process draws from the prophetic tradition that goes beyond prediction of time- space events to discerning the interior realities of manifest events. It is like looking into the seeds of the present time to say which seed will grow and which will not; or, with a change of imagery, discerning what is going on beneath what is happening. The prophetic capacity is a gift as the Holy Spirit empowers and opens the eyes of God's servants to see beneath events. The prophet could go further and become a watchman, perched on the security tower of a community to warn them of the approach and devices (stratagems or wiles) of the enemy. The prophet both tells the people about the mind of God and warns of impending dangers. The tasks are performed with no concern for personal physical risk because of a compelling mandate, a fire in the bones, to ensure that no one is lost because the person was not warned. If the people heard but chose to ignore a warning, God will excuse the responsibility of the watchman. Like a courier, the prophet speaks God's word to the people and the people's concerns to God. The tradition combines the tasks of prophesying, keeping the daily watch, and interceding under the power of the Holy Spirit.

Throughout the story of Christianity, there have been moments when the leaders have woken to their prophetic and watchman roles especially when boars raid the vineyard or political rulers, as madmen, seize the priest's role and wield the sacred rod in the temple. In such moments of crisis, leaders invoke God to ensure that the legitimate rod should bud. But the problem is hardly that simple precisely because the boundaries of the sacred roles of princes have been contested through time with biblical authority lined up behind both sides of the fence.

The churches in Germany witnessed such a crisis moment in 1933/4 when the Weimar Republic collapsed under the weight of military defeat, the decease of the democratic liberalism and the resurgence of National Socialism. The nature of the challenge must be spelled out clearly precisely because it was not about the freedom of worship as many foreigners concluded in their efforts to support the beleaguered churches of Germany. During a visit to Britain, Karl Barth strained to correct the impression and specify the type of action that could aid the brethren in Germany:

"The fight is not about the freedom, but about the necessary bondage of the conscience; and not about the 
freedom, but about the substance of the church, i.e. about the preservation, rediscovery and authentication of the true Christian faith” (Clements 1986:15-24).

He insisted that German Christians did not require material aid or protest letters addressed to the state; rather, their urgent need was for Christians in foreign lands to join them in affirming a common confession in the midst of the intervention of the German Reich to repackage Christianity. The Anglo-Saxon audience must have been puzzled. How can a confession adequately serve as a tool of protest?

\section{THE WATCHMAN AND THE PEOPLE: CONFESSION AS BEING, DOING AND SAYING}

Christians have used different types of confessions in expressing beliefs and rituals such as the baptismal, doxological, confession of guilt and drawing the boundaries of doctrinal belief. Most people may be more familiar with the doctrinal forms used in settling disputes about matters of belief. These became increasingly familiar in the intra-mural warfare within the scions of the Reformation. However, situational confessions are slightly different and serve as instruments for crisis moments; as a re-definition of the relation between the Christian confession and political reality; a composite image of the being, saying and doing of the body of Christ in such times. They speak to localized crisis situations and, therefore, betray four characteristics: they react and respond to a situation or context; they are embedded in a specific ecclesial structure; advocate a certain activity, and boldly distinguish between the legitimate and illegitimate forces operating underneath manifest events.

In the Barmen Declaration of 1934, a synod of some German Evangelical Churches met to react to the dangerous secular and ecclesial contexts in which many evangelical churches, mission boards, academy, prominent theologians and missiologists supported the National Socialist cause; used biblical and theological resources to legitimize the regime; supported the re-organization of the church structures; aided the state creation of a Reich church (Reichskirche) with a bishop; tolerated the Aryan clause and anti-Semitist diatribe of the regime; and aligned missionary policies of volkschirche with a tribalist ideology based on blood, soil, racial purity and national destiny. The Lutheran mission of Neuendettelsau, Bavaria, for instance, was so deeply 'Nazified' that they made their mission candidates join the Brown Shirts. There was a widespread conviction 
within the missionary bodies that Nazism would aid missions to achieve their goals, and the ideology would reunite mission with churches, an idea that the doyen of European missiology, Gustav Warneck harped upon. The anti-liberal and anti-communist invectives equally appealed. The nature of this collusion became more apparent when in 1993 Werner Ustorf discovered the Minute Books of the Council and Federation of German Protestant Missions, 1924-1949. The secretary, Walter Freytag (1899-1959) had left them with his personal secretary, Frau Ursula Ebert, with instructions to keep them private (Ustorf 1997:63-82).

Robert P Ericksen (1985) has tried to show how incredibly a welter of respectable intellectuals such as Gerhard Kittel, Paul Althaus and Emmanuel Hirsch provided the ideological prop for Hitler whom he describes as "a political answer to a very difficult question". Most intriguing in this trio was Paul Althaus who lacked the opportunism of Kittel and the acerbic character of Hirsch. Regarded as the gentleman intellectual by colleagues, he nevertheless turned his immense resources to promote National Socialism. His reading of the background to the groundswell support for Hitler deserves attention.

"As a Christian church, we bestow no political card. But in knowledge of the mandate of the state, we may express our thanks to God and our joyful preparedness when we see a state which after a time of depletion and paralysis has broken through to a new knowledge of sovereign authority, of service to the life of the volk, of responsibility for freedom, legitimacy, and justice of volkisch existence. We may express our thankfulness and joyful readiness for that which manifests a will for the genuine brotherhood of blood brothers in our new order of the volk...We Christians know ourselves bound by God's will to the promotion of National Socialism, so that all members and ranks of the volk will be ready for service and sacrifice to one another" (Ericksen 1985:86).

The collusion of the German churches with the socialist forces started shortly before Hitler came to power when The Faith Movement of German Christians organized and brewed a theology in which the gospel was interpreted with a lens inscribed with a racially construed manifest destiny. In July 1933, Hitler could easily sign an order based on an agreement with the leaders of the regional 
churches to create a national German Protestant Church. Thus, the harmonization of throne and altar, fatherland and church, gospel and patriotism created both a crisis moment and embedded an ecclesial structure that violated the inner core of the presence of the kingdom of God in the communities.

Some leaders responded: Martin Niemoller founded the Pastors' Emergency League in September and mobilized the Confessional Synod of the German Evangelical Church at Barmen, May 29-31, 1934, to respond and advocate a specific activity in rebuttal and at a great risk. It was not a matter of religious freedom precisely because the churches were not restrained from worshipping. Much to the contrary, it is reported that the Baptists told their British counterpart that they had never been freer as under the Reich; the Free Church communities welcomed Hitler's accession to power as guaranteeing security and privileges and the Vatican signed a concordat with the Nazis. Thus, the situational confession at Barmen was designed to respond to challenges from two directions; externally, from the state and more cogently from the Christian communities that allowed nationalist allegiance to contest their Christian commitment. The core concern was how a church responds in a crisis moment when the dominant culture essays to overawe the gospel's affirmations and destroy the unity of the Christian community. The protest group that converged at Barmen rejected the collusion with the state. It sought to declare that certain modes of action and attitudes were incompatible and irreconcilable with Christian convictions. Dismayed that believers were on both sides of the conflict, it sought to focus on an action that would recreate the unity of faith rather than the union of the churches; give the churches a definite profile; and a clear, prophetic voice "in their decisions in church politics" (art. 6).

The strategy is germane. First, Barmen conferees did not contest the creation of a national church but claimed to be the church. They imaged the contemporary union church as illegitimate, based on a false understanding of the source, role and dynamics of church governance. Second, they intentionally seized the high ground from which to make the voice of the church heard; that high ground was the freedom and power of the word. They shared Bonhoeffer's insistence in his lecture, "Protestantism Without Reformation" that "the essential freedom of the church is not a gift of the world to the church, but the freedom of the Word of God itself to 
gain a hearing” (in Robertson 1965:104). As article six of Bremen Declaration intoned, "the word of God is not fettered". It has its own power and freedom and life span that extends into the eschaton. Third, they focused on the affirmation of the inner core of the Christian faith as the location of the identity of God's people. The process or action in proclaiming these truths (doing and saying) reinforces being. Thus, they employed the model of a doctrinal confession in six theses. Fourth, they avoided a direct confrontation with the state but focused on the church's response to the matters of identity, task and life-style, source of authority and 'the bounds of either sword', as John Milton put it. Defensive drivers are usually advised to avoid the glare of oncoming vehicles and focus on the centerline of the road. This is what the leaders at Bremen did.

\section{TALKIN' AND TESTIFYIN': BARMEN, CONE AND BLACK POWER}

They insisted that their goal was to explain the current situation. This declaration or explanation combined the prophet's role to stand on the word of God and stubbornly declare it, with the watchman's role to warn against obvious dangers of cankerworms in the body of Christ. As Jeremiah Wright's contribution on "underground theology' in Black Faith and Public Talk put the matter, it brings to the surface the power of a hidden "underground theology" that pulsates beneath the hard surface of the institutional structure (Hopkins 1999b:96-102). Thus, the common style in all the six theses would begin with a biblical passage; followed by a thesis or appropriation of the text; and a counterpoint that serves as anti-thesis or exposure of an incipient false teaching. The structure placed theology at the center of political ethics and pursued an ecumenical response or common confession amidst corrosive circumstances. Intriguingly, it employed a prescriptive ethical norm that was Biblical, unabashedly Christo-centric and quite typical of Karl Barth who sole-authored the declaration. However, commentators have rooted some of the theses into the soil of earlier confessions such as the Heidelberg Catechism, Second Helvetic Confession, Dusseldorf Theses (1934) and Ten Theses of Bern of 1528. He did not ignore the heritage of the community but built upon it and upon the uniqueness of Christ (Dowey 1968:255-6).

There is a sense in my madness that starts a reflection on Professor James Cone's legacy in Africa from such a far distance. On a closer look the distance is not that far because (i) the intention 
here is to examine the impact of Professor Cone's prophetic theological ethics, especially how he influenced the rise of black liberation theology in South Africa and the Kairos Document. (ii) It is argued that Professor Cone was much enamored with Barth's theology of the word: proclaimed, written and revealed, the role that Barth assigned to the church as a bulwark against the authoritarian and repressive state, and his trenchant Christology. He selected from him and other white theologians to make his point. As he himself confessed,

"I am embarrassed by the extent of my captivation by white concepts. And I realize that I am still partly enslaved by them. The struggle to overcome this enslavement has been a constant struggle in my intellectual development. That is why I will always indebted to my black colleagues for assisting me in this endeavor" (Cone 2004:77).

Black Consciousness Theology in South Africa used the Barmen confessional strategy as a model of political praxis after the scorching Soweto crisis. While the format was Barthian, the content was, would we say Conish? This is because the condition in South Africa in 1986 was similar to the conditions in the United States in 1968.

People have responded to Cone's political theology in various ways. His book, My Soul Looks Back is a touching response that shows that he is always prepared to be challenged, to learn and to pursue the goal with an intense passion. He advocates the highest level of academic rigor and dialogue for black scholarship. He insists that the black church must become the agent for liberating the black poor; therefore, it is vulnerable to criticisms from its theologians; and the theologians must equally be open to the mutual criticisms from the black church because

"Black theology must be a church discipline, true to itself only when validated in the context of people struggling for the freedom of the oppressed. Its chief task is to help the church to be faithful to the task of preaching and living the liberating gospel of Jesus Christ in the world today" (Cone 2004:77).

Doing black theology is not an academic enterprise but is a matter of life and death. Professor Cone's prophetic ministry was born in the 
summer heat of untoward events, and has retained the fiery mark of urgency, a task for the Gideon Company, a process that is always retooling, constantly searching for institutional and human agencies that could carry the task to its fulfillment. As Cornel West said in his contribution to Black Faith and Public Talk, one should consider Cone's cry from the heart in the context of

"the corpses of young black folk...(and) 329 uprisings in 257 cities between 1964-1969. After 212 uprisings on the night that the bullets went through the precious body of Martin Luther King Jnr., America can no longer deny the fact that either it comes to terms with the vicious legacy of white supremacy, or the curtain will fall on the precious experiment in democracy called America" (Hopkins 1999b:12-13).

Like Karl Barth's endeavor in the Barmen Declaration, it was a brand of crisis theology. Black theology was the theological arm of black power seeking to relate the black struggle for freedom to the biblical claim regarding the justice of God. Black power itself was the political challenge to the non-violence preached by Martin Luther King. It was built on the Bible as the core and the Christocentric-driven theology nicknamed, "Jesusology", that captured black Christian imagination and flowed profusely into preaching understood as the work of the Spirit (Cone 2004:81). Blackness was the context, the reason for the oppression by whites, and the question is whether theology could serve as a tool of liberation of the black person from white oppression.

Cone met the ethical challenge by rejecting white theology as biased tribal reading of the Bible and reflection, and reaffirming a certain understanding of God: God's love must be understood from the perspective of His partiality and love for the poor. God manifested His divine freedom by creating human beings in His own image (imago Dei). God demonstrated His justice, righteousness, and salvation by entering into the depths of humanity's pain and oppression to liberate them from demonic forces or structures of racism and forces of domination. His kingdom stands for poor people's hope and empowers them to organize and achieve their liberation in human history. The cross and resurrection become channels of liberation from the material bondage crafted by principalities and powers. Heaven is the ultimate destination of a new beginning without an end, a place of rest after a well-fought 
fight here on earth. Within this perspective, reconciliation could only be achieved by firstly achieving the freedom of the poor. The victims set the conditions. Perhaps, the oppressors might change and become reconciled to oppressed blacks. Before the white man removes his boot from the face of the fallen black person, there could be no meaningful discussion about reconciliation. As Dwight Hopkins (1999a) summarized the matter in his Introducing Black Theology of Liberation, the foundations of black theology between 1966-1980 were: slave religion, reinterpretation of the Bible, the broad political and cultural currents within the civil rights and black power movements, a new method of doing theology, and conversations with and insights from the decolonization experiences of black peoples and movements in the southern hemisphere. This stark summary has deliberately highlighted the key aspects of Cone's theology that attracted Africans. Theology is not heuristic but the reflections by human beings about the relationship of God to human beings and the world of nature. It is God-talk in human situations.

\section{BLACK MAN, YOU ARE ON YOUR OWN!: CONE AND KAIROS DOCUMENT IN AFRICA}

James Cone had a long empowering conversation with African and Third World Theologians in Accra in December, 1977. It was a very defining encounter in the refining of his theology. He faced the difficult assertion by some African theologians that black theology was different from African theology. He faced the double consciousness of having African and American roots, and the universal claim of common faith in Christ. He was confronted by the insistence by some, like Professor John Mbiti, that African theology must emerge from the written, oral and symbolic production of the people of God. The debate was somewhat misunderstood and it should be useful to summarize Mbiti's theological positions.

John Mbiti, a Kenyan scholar, pioneered the articulation of African Theology. In his doctoral dissertation at Cambridge University in 1963, he used the concept of eschatology to expose the underlying task of African theology. He distinguished between the layers of what the New Testament taught, what missionaries conveyed to the Akamba people, how the Kikamba conceptualized life after death in their indigenous worldview, and, therefore, how they decoded missionary teachings, by appropriating some elements and reconfiguring these through the prism of their worldview. In culture contacts, despite the efforts by hegemonic forces to implant 
certain doctrines, hearers appropriate the gospel from their worldviews. The gospel is an eternal gift of God but Christianity is an indigenized structure. The bearers brought the gospel repackaged with a western cultured and enlightenment worldview. They privileged literacy, and communicated in various European vernaculars to people who emphasized orality, narrative theology, maximum participation in liturgy, inclusion of visions, dreams, and a relationship between body and mind manifested through healing and prayer. The question is: what did the hearers hear and say about the relationship of God to human beings and the world of nature? This is theology or God-talk.

Mbiti refused to castigate missionaries while rejecting the denigration of indigenous religions and cultures. He argued that the sources of doing theology comprise of the Bible as the source of divine revelation, the indigenous worldviews, religions, cultures, oral reflections by the people of God, the existential forces in their environments, the heritage of Christian traditions and the presence of other religious faiths. African Christianity results from the encounter of the gospel with these factors. Mbiti's conclusion that African religions and cultures embody a preparation is crucial for the gospel because Christ is in every culture and judges all cultures. African Christianity is a continuum with dimensions of African religions such as the celebration of life and corporate sense of existence. God is one and has been known and worshipped in various ways by African peoples before the missionaries arrived. This explains the wide areas of resonance between African and Biblical worldviews: a charismatic perception of reality; a three dimensional perception of space; the dynamic relations of "here and now" to the "not yet" period; the power in the blood, name, and words; the reality of miracles and supernatural interventions in daily lives. All these are and many more serve as pathways for inculturation. However, there are differences. The African perceives time as an event (kairos); life flows in a cyclical fashion from birth through death to reincarnation. The New Testament perceives time as abstract (kronos) that moves in a linear fashion from the past through the present to the future. Mbiti's conception of the future in African thought has elicited much debate. The African's fascination with the Bible indicates a cultural appreciation of the similar contents of its world. This explains the Hamitic theories of origin found among many Bantoid-speaking African people. 
Mbiti, therefore, studied African religions and cultures (focusing on shared elements), concepts of God, prayers, love and marriage and the use of the Bible. Combined with his vernacular poems and anthropological studies, he rehabilitated Africa's rich cultural heritage and religious consciousness, and brought them into Christian theology, and thereby removed the veil of strangeness of the gospel among African communities. He showed that prayers, libations, sacrifices, dance music, rites of passage, festivals were means of weaving covenants with the Supreme Being, spirits and ancestors and to ward off evil. He showed how these could be redirected towards God in a conversational process. The task of communication was the church's major task. A key instrument is the translation of the Bible into the vernacular. Vernacularization removes the slur from indigenous cultures. It means that God is not partial to any race of people. Indeed, Africans have tended to emphasize the pneumatic resources of the gospel because of their charismatic worldview. Mbiti, therefore, paid attention to the creative liturgy and theology of African Indigenous Churches. Employing a phenomenological approach, he sidesteps the typologies developed by anthropologists.

Mbiti recognized that the core of gospel-culture encounter is the role of Christ. Other scholars canvassed the notion of Christ as ancestor. Mbiti argued that Christ answers the search for meaning and wholeness in every culture including African religious life. Christ completes the sacralization of the whole of life that removes the veil between the sacred and the profane. In Africa, the human world is a mirror of the spirit world. He is the crowning completion of all quests, the brilliance of the flickering light in world religions. Other scholars have tried to image the face of Jesus in Africa as a chief, king, ancestor and guest. These imageries fail to capture the full Jesus. Mbiti focused on Christ's meaning and lordship over life, reconciling the whole of creation to God. He has worked on ecotheology in Africa.

Mbiti's theology made an enormous impact in the African academy and church life. He interpreted Africa to the universal church and academy. As an evangelical Anglican priest, his concern was the communication of the Bible in Africa. However, he lacked a strong political theology as espoused by the liberation theologians. This left the impression, as John Parratt has commented upon, that 
there are two genres of African theology, the cultural and political (Parratt 1995:1-24).

On the other hand, Cone dealt with the contextualization problem by reclaiming his African origins. He balanced the cultural and political concerns of theology and concluded that "there is some sense in which the black world is one", with an "inextricably bound" future and common historical option. Economic and political domination, racism and oppression compel solidarity and recovery of our history to achieve liberation. He refused to abandon the social context of theology. As he argued,

without the indigenization of theology, liberation theology's claim to be derived from and accountable to oppressed peoples is a farce. Indigenization opens the door for the people's creative participation in the interpretation of the Gospel for their life situation. But indigenization without liberation limits a given theological expression to the particularity of its cultural context. It fails to recognize the universal dimension of the gospel and the global context of theology (Appiah-Kubi, Kofi and Torres 1979:178, 184).

Cone elicited much support from a number of African theologians. It must be asserted that it was from his influence rather than from Latin America that liberation theology gained enormous reputation in Africa. His impact was particularly felt in Southern Africa because, when other regions of the continent were hoisting their new flags, learning new national anthems, and celebrating political independence, repressive regimes bared their fangs in the southern region. In West Africa, for instance, the major theological task was the search for an indigenous theology relevant to African culture. But in South Africa, Cone's first publications created a political wave and reanimated a desultory political terrain. They reshaped the political discourse because the harsh state reaction against protests groups after Sharpeville scorched the political terrain. The old brigade of African freedom advocates were imprisoned, exiled or driven underground.

Ironically, the establishment of black universities and homelands backfired as a new band of urban, educated detribalized students came to the fore. They rejected the homelands and the repressive apartheid regime, and found the new theology as a clear 
articulation of their anger and hopes. These young people were mostly brought up in black townships as Soweto, Umlazi, New Brighton and Langa. They had studied at the recently founded black ethnic universities of Zululand, the North, Durban-Westville, Western Cape and the older Fort Hare. Across denominational and ethnic divides, they started debates on black theology, and reinvented the sedate organizations such as the University Christian Movement and the Students' Christian Movement into radical black activist groups. The new wine tore the old wine skin and shredded the students' unions. New leadership emerged such as Steve Biko. This is briefly the background of the Black Consciousness Movement. Their battle cry was simply put: black man, you are on your own! They lost the innocence that the white man could do anything good for the black man. They struggled and debated on how best to appropriate the insight to fit their condition, and ground the new theology into the primal ethical values as kinship, community, identity, and ubuntu. When they published Essays in Black Theology in 1971, the government heard the message loud and clear and banned the book and exiled Basil Moore, the secretary of UMC (Moore 1973). Allan Boesak (who took copious notes at the Accra conference when Cone and Mbiti debated the relationship between black and African theologies) explained in 1977 in Farewell to Innocence that for these young men,

Black Consciousness may be described as the awareness of black people that their humanity is constituted by their blackness. It means that black people are no longer ashamed that they are black, that they have a black history and a black culture distinct from the history and culture of white people. It means that blacks are determined to be judged no longer by, and to adhere no longer to white values. It is an attitude, a way of life. Viewed thus, Black Consciousness is an integral part of Black Power. But Black Power is also a clear critique of and a force of fundamental change in systems and patterns in society which oppress or which give rise to the oppression of black people. Black theology is the reflection of black Christians on the situation in which they live and on their struggle for liberation.

The farewell message, like the separation period in a ritual of passage, is deliberately quoted in extenso to demonstrate the impact 
of Cone's ideas on the young people as they bade farewell to innocence. Their position was not derivative but deeply decoded what their black brother from across the great lake said. Indeed, Boesak adopted the idea from Rollo May's concept of pseudoinnocence that keeps a black person from realizing the power of bondage by racist structures on one's whole being. He argued that he was brought up within a Dutch Reformed tradition in which they swore by Abram Kuyper. Then he gained a new consciousness of who he really is. He realized that he lived in a structure governed by "pigmentocracy"; and that the task is both to liberate the gospel from misuse by whites and to address the existential situation. It is a situational theology.

Archbishop Desmond Tutu insisted that liberation theology was not an academic matter because "it issues out of the crucible of human suffering and anguish. It happens because people cry out, 'Oh God, how long'. And of liberation theology is a sense really a theodicy. It seeks to justify God and the ways of God to a downtrodden and perplexed people” (Appiah-Kubi, Kofi and Torres 1979:163). He was writing soon after the murder of Steve Biko and acknowledged that this theology was inspired by the experience and spirituals of Americans (Appiah-Kubi, Kofi and Torres 1979:164). Like Cone, Tutu declared in 1977 that

we are engaged in something too urgent to wait for the approbation of the West or those who would blindly follow western standards of acceptability and play western games using western rules.

Much to the contrary,

other theologies are challenged to become more truly incarnational by being concerned for the whole person, body and soul. They are called upon to glory in their inbuilt obsolescence, not to cry out for permanence and a validity that properly belongs only to Gospel of Jesus Christ (Appiah-Kubi, Kofi and Torres 1979:168).

Then the calabash of blood broke on their heads as the Soweto riots challenged the renaissance of black political hopes. A feverish response followed as a number of Christians worked together through several months to declare the mind of the people of God on the political situation in 1986. The Kairos Document x-rayed the apartheid system that was established in 1948 and became most 
brutal from the 1960's. Both the Sharpeville uprising in 1960 and the Soweto riots in 1986 indicate that the regime faced equally unrelenting challenges. Some Christians under the umbrella of the South Africa Council of Churches were moved by the example of the Germans in 1934 to speak prophetically against the antics of the mad rulers and the unfaithfulness of some churches. They were not the whole church because the three branches of the Dutch Reformed churches (NGK, NHK, GK) supported apartheid from similar reasons as the 'German Christians' who supported Hitler. They deployed covenant theology, natural theology, race, blood, soil and the history of the Boers in South Africa. In Pretoria, they constructed a huge monument that inscribed on granite a certain view of history about the suffering people's great, exilic trek to a land that God gave them. The divine duty was to drive away all the inferior races and occupy till Christ returns. The academy especially at Stellenbosch provided the intellectual arsenal for separate development of the races. The cursory proof-texting in their use of the Bible was betrayed in a debate on the Scripture and Apartheid that raged in the pages of the NGK's Die Kerkbode. Professor P V Pistorius (19071972) of the University of Pretoria attacked his colleague, B J Marais who in 1948 dared to suggest that there was not a line in the Scriptures to buttress the church's support for apartheid:

I read: 'Honour your father and mother'. For that reason I practice colour apartheid because the inheritance of my fathers and mothers would disappear in colour mixing. 'You shall not commit murder'. I read, and because I know that colour mixing will lead to the death of our volk and Western civilization here in South Africa, I practise apartheid (Hofmeyr et al 2001:22).

The white Pentecostals accepted it with a strong apolitical theology to the point of using the support of the American Right to legitimate the regime (Gifford 1991). When Frank Chikane, a minister of the Apostolic Faith Mission, joined the SAAC in its protests against apartheid, the church defrocked him. The Baptists used a doctrine of the separation of church and state to urge their members away from political engagement. The African Independent Churches encouraged their people to avoid the political terrain like the plague and created ritual havens where the wounds of the system could be healed (Anderson 2003). A wider band of Christians such as the 
Anglicans and Catholics remained ambivalent. John de Gruchy stated the matter rather crisply:

neither the Roman Catholic Church nor the various Lutheran synods have been in the forefront of the struggle against racism in South Africa until fairly recently (De Gruchy 1979:97).

He explained the dilemma of the Catholics as well as the revolt of the black priests. Only a few Christians opposed the system. Collaboration, withdrawal, ambivalence and opposition fragmented Christian responses to the state. Thus, South Africa shared similar challenges as Germany; challenges that emanated from both the state and within the Christian family. They shared the same dilemma as the black churches in the United States that frustrated Cone into a severe criticism of the black church until he feared that the whites might steal the thunder for a desperately heinous activity.

The Kairos Document came like an uncomfortable sound of the ram's horn. It was neither the first confession nor would it be the last but came at a particular point in the story of apartheid and with a unique style. As an antecedent, in 1979, the Broederkring, a group of non-white ministers and evangelists of Dutch Reformed churches, founded in 1974, used a five-point confession that sounded like a reharsh of Bremen to bear witness to the liberating acts of God who stands on the side of the oppressed. As some articles declared their goal:

2. To take seriously the prophetic mission of the church where the oppressive structures and laws in Southern Africa are concerned and furthermore: the priestly mission, where the victims of the un-Christian policy and practices of these countries are concerned, including the fearful oppressors themselves...3. To let the Kingship of Christ triumph over the ideology of apartheid... (Vischer 1982:20-22).

It made little impact on the public space.

Indeed, John W de Gruchy has argued that between the Cottesloe Consultation in 1960 and the Rustenburg National Conference of church leaders (November 5-9, 1990), many efforts were made to discuss the moral implications of the legitimization of the apartheid system on the basis of the Scriptures because internal 
dissent was slowly brewing: some church leaders wanted the argument from necessity to replace the biblical ones while a few dared to swim against the currents by declaring apartheid as unbiblical. As the Dutch churches retreated from ecumenical endeavors after 1960, internal opposition, however weak sprouted. Beyers Naude started the Christian Institute that issued The Message to the People of South Africa (1968). The World Council of Churches between 1966-68 took a more radical route to combat racism by supporting the churches in South Africa that opposed the regime. By the 1970's Africa Enterprise appeared on the scene with more radical goals. The emergence of liberation theology in the late 1970's inspired many in South Africa and elicited more radical options. Two routes faced the churches, reform or revolution. Thus, the appearance of the Kairos Document signaled the rise of younger opposition that was highly critical not only of the NGK and its doctrine of apartheid but the reformist, liberal English-speaking churches and other members of South Africa Council of Churches who had been preaching peace, reconciliation and reform. As Allan Boesak intoned during the WCC General Assembly, Vancouver, in the summer of 1983, there cannot be peace without justice!

After Soweto crisis, there was a rejection of cheap reconciliation. The stakes were raised as the landscape changed. The black political spectrum shattered: the non-violent ideology of the United Democratic Front (UDC) no longer spoke for many. Equally contested were the universal visions of $\mathrm{Z} \mathrm{K}$ Matthews and Albert Luthuli representing the ANC. More people inclined towards the anti-white position of Robert Sobukwe (one of those arrested in the aftermath of Sharpeville) and his Pan African Congress (PAC) as well as the black liberation theology of Steve Biko and his Black Consciousness Movement (BCM) that focused on the violent reaction of Jesus to the oppressors who trafficked at the expense of the poor. It may be argued that Tutu's sword in the ploughshare policy and his march to Parliament in 1988 represented Barmen more faithfully even as the spectrum shifted to more revolutionary prescriptions (Kalu 2000:99-100). The similarity between Martin Luther King's position and the violent criticism of the Black Power could not be lost upon the readers.

Thus, while similarities existed with Barmen, many discontinuities are palpable: the Barmen Document was authored by a single person and used a doctrinal confessional style. The Kairos Document 
was written by a group and signed by a large number of Christians from different churches. They bridged over ethnic consciousness that hampered the efforts of the older generation, and the denominational gullies that missionaries dug. The contents resonated more with Cone's idea than with Marxist purists. It may not have the theological clarity or succinctness of Barmen but it theologized more elaborately and contained a deep social analysis of the state. It used a liberation theological model to engage in a trenchant description and critique of the contemporary regime. Its real title stressed a "theological comment on the political crisis in South Africa". It was a situational confession whose four cardinal aspects were: first, a critique of state theology that misused Paul in its tendency to brand all opposition as communist. The illusion was that South Africa was the bastion of Western democracy against Communism. During the cold war, American foreign policy bankrolled the myth. Second, it attacked the church theology of the ambivalent group that employed middle axiom to preach reconciliation. The document invited them to distinguish between mere quarrels and conflicts in the household of faith from structural injustice. This required the examination of the concept of justice because an unjust political dispensation deserved a radical response and total dismantling, not reformation. Third, the context recalls the preference for the poor, marginalized and oppressed in the ministry of Jesus. Fourth, it combined a contextual or prophetic theology with searching questions about life in South Africa. It interpreted Scriptures for those conditions in profoundly new ways. Later, Jurgen Moltmann (1990:102) in his The Way of Jesus validated the Kairos Document's approach when he argued that the role of Christian political theology was to interpret the dangerous memory of the messianic message of Christ within the conditions of contemporary society in order to free human beings practically from the coercions of society and to prepare the way for the eschatological freedom of the new humanity.

But in 1986, many white liberals accepted the social analysis of the Kairos Document but dreaded the revolutionary option and its alleged empowerment of the leftists. Violence increased as other geopolitical forces gathered to thwart the confidence of the apartheid state. Soon, the pillars of apartheid buckled as more critical voices emerged from university professors who wrote joint appeals to the state. Even the conscience of lay Christians stirred. But it was the black force, roused by the Kairos Document that countered 
apartheid. Many died at the twilight of victory just as Bonhoeffer. But the interest here is how Cone's prophetic speaking inspired blacks and whites in South Africa who appropriated its resources for their own context and adapted it to suit their own situation.

Some people considered the Kairos Document as a protest that signaled the prophetic, non-violent posture against a violent, mad structure as untenable. They read it as a document that inspired resistance. The being and saying of the church as defined by the protesters should compel the basis of doing a different type of political action that went beyond the ambiguous protests by the English churches. This South African case study shows how Christians all over the world will continue to hear both Cone's theology and the Barmen model of using confession as political praxis. Each context would appropriate its resources in different ways for decision-making in troubled times. This is what contextual method of doing theology is all about.

\section{Consulted Literature}

Anderson, A 2003. "Pentecostals and Apartheid in South Africa During Ninety Years, 1908-1998” http:/www.pctii.org/cyberj/Anderson.html

Appiah-Kubi, Kofi and Torres S (eds) 1979. Africa Theology Enroute Maryknoll, NY: Orbis.

Clements, K W 1968 "Bonhoeffer, Bremen and Anglo- Saxon Individualism" Journal of Theology for Southern Africa (JTSA), 54, (March): 15-24

Cone, J H 2004. My Soul Looks Back. Maryknoll, NY: Orbis.

Dowey, E A. 1968. A Commentary on the Confession of 1967 and An Introduction to the Book of Confessions. Philadelphia: The Westminster Press.

Ericksen, R P 1985. Theologies Under Hitler. New Haven: Yale University Press.

Flett, J 2003. “ From Jerusalem to Oxford: Mission as the Foundation and Goal of Ecumenical Social Thought" International Bulletin of Missionary Research, 27/1: 17-20

De Gruchy J W 1979. The Church Struggle in South Africa. Grand Rapids, Eerdmans.

-, 1991. "From Cottesloe to Rustenburg and Beyond” JTSA, 74: 21-34

-, 1995. Christianity and Democracy. London: Cambridge University Press.

Gifford, P 1991 The New Crisaders. London: Pluto Press.

Hofmeyr, J W et al (eds.) 2001. 1948+50 Years: Theology, Apartheid and Church. University of Pretoria, IMER Publications. 
Hopkins, D 1999a. Introducing black theology of liberation. Maryknoll, NY: Orbis.

-, 1999b. Black Faith and Public Talk: critical essays on James H Cone's Black Theology and Black Power Maryknoll, NY: Orbis.

Huber, W 1991. "The Barmen Declaration and the Kairos Document on Relationship Between Confession and Politics” JTSA, 75: 48-60

Kalu, O U 2000. Power, Poverty and Prayer: The Challenges of Poverty and Pluralism in African Christianity, 1960-1996. Frankfurt, Peter Lang.

-, 2003. "Remembering South Africa: Kairos Document, Religious Commitment and National Identity" World Mission Institute Workshop, Chicago, April 22nd -23rd

Moltmann, J 1990. The Way of Jesus: Christology in Messianic Dimensions. London: SCM Press.

Moore, B 1973. Black Theology: the South African Voice. London: C.Hurst.

Parratt, J 1995. Reiventing Christianity: African Theology Today. Grand Rapids, Eerdmans.

Robertson, E H ed. 1965. No Rusty Sword London, Collins.

Rohls, J 1998. Reformed Confessions: Theology from Zurich to Barmen Louisville, Westminster John Knox.

Smith, G 1997. "Be of Good Cheer": Christian Mission Confronts Social Disintegration in the 1937 Oxford Conference" In Lynne Price et als eds Mission Matters. Frankfurt, Peter Lang, 49-62.

Ustorf, W 1997. "The Documents that Re-appeared: The Minute books of the Council and Federation of German Protestant Missions, 1924-1949” Mission Matters, 63-82.

Vischer, Lukas ed. 1982. Reformed Witness Today: a collection of Confessions and Statements of Faith Issues by Reformed Churches Bern: Evangelische Arbeitsstelle Oukumene Schweiz.

-, 1983. The Constitution of the Presbyterian Church (USA):Part 1: Book of Confessions. General Assembly, Louisville, Ky., 1983:8.01-8.28 